\title{
Mapping Knowledge and Training Needs in Teachers Working with Students with Autism Spectrum Disorder: A Comparative Cross-Sectional Investigation
}

\author{
Ruxandra Folostina ${ }^{1}(\mathbb{D})$, Cristina Dumitru ${ }^{2} \mathbb{D}$, Claudia Iuliana Iacob ${ }^{1, * \mathbb{D}}$ and Christine K. Syriopoulou-Delli ${ }^{3}$ \\ 1 Faculty of Psychology and Educational Sciences, University of Bucharest, 050663 Bucharest, Romania; \\ ruxandra.folostina@fpse.unibuc.ro \\ 2 Faculty of Educational Sciences, Psychology and Social Sciences, University of Pitesti, 110040 Pitesti, Romania; \\ cristina.dumitru@upit.ro \\ 3 School of Social Sciences, Humanities, and Arts, University of Macedonia, 54006 Thessaloniki, Greece; \\ csyriop@uom.edu.gr \\ * Correspondence: claudia.draganescu@unibuc.ro
}

check for

updates

Citation: Folostina, R.; Dumitru, C.; Iacob, C.I.; Syriopoulou-Delli, C.K. Mapping Knowledge and Training Needs in Teachers Working with Students with Autism Spectrum Disorder: A Comparative Cross-Sectional Investigation. Sustainability 2022, 14, 2986 https://doi.org/10.3390/su14052986

Academic Editors: Dunja Anđić,

Nena Rončević and Michele Biasutti

Received: 1 February 2022

Accepted: 1 March 2022

Published: 3 March 2022

Publisher's Note: MDPI stays neutral with regard to jurisdictional claims in published maps and institutional affiliations.

Copyright: () 2022 by the authors Licensee MDPI, Basel, Switzerland. This article is an open access article distributed under the terms and conditions of the Creative Commons Attribution (CC BY) license (https:// creativecommons.org/licenses/by/ $4.0 /)$.

\begin{abstract}
Countries seek to implement sustainable policies for supporting professionals working with students with an autism spectrum disorder. These policies can advance more slowly in developing states like Romania and Greece. As such, this study aimed to investigate the reported knowledge and training needs of professionals working with ASD students to inform policymakers. Using a crosssectional design, 475 Romanian and 211 Greek specialists completed an online questionnaire on the following dimensions: diagnosis and assessment of ASD, management of behavioural problems in ASD students, communication skills, technology, teaching, and e-learning platforms. The results showed that Greek professionals have higher levels of ASD knowledge compared to Romanian respondents $\left(\mathrm{M}_{\text {Greece }}=15.2, \mathrm{SD}_{\text {Greece }}=4.22 ; \mathrm{M}_{\text {Romania }}=13.7, \mathrm{SD}_{\text {Romania }}=3.88 ; \mathrm{U}=39703, p<0.001\right)$. There is also a significant need for training on all the investigated dimensions in both countries, with greater training needs in Romania than in Greece $\left(\mathrm{M}_{\text {Greece }}=26, \mathrm{SD}_{\text {Greece }}=2.98 ; \mathrm{M}_{\text {Romania }}=27.2\right.$, $\mathrm{SD}_{\text {Romania }}=1.84 ; \mathrm{U}=35556, p<0.001$ ). Both countries reported the lowest level of knowledge in innovative teaching technologies and high training needs using an e-learning platform. The results emphasise important gaps in the educational programmes for ASD professionals.
\end{abstract}

Keywords: training needs; teachers; e-learning; ASD knowledge; teacher education

\section{Introduction}

Autism spectrum disorder (ASD) is a lifelong neurodevelopmental disorder, identified by behavioural symptoms such as poor social interactions, qualitative impairments in verbal and nonverbal communication, narrow interests, and stereotyped behaviours [1], which hinder a child's adaptation. Children with ASD face many challenges, with serious barriers and difficulties in leading independent lives [2]. Language development and communication (i.e., exchanging information between persons, using the same system [3]) are usually slower and present particular characteristics, such as repetitiveness, rigidity, and poor nonverbal skills [4]. Due to these features and the overwhelming environment, children with ASD often display emotional and externalising behaviours (e.g., aggression, self-injuries, non-compliance) called conduct or "problem behaviours" [5]. These challenges are distressing for both parents and educators [6,7]; therefore, assessing and addressing them through interventions is crucial for recovery and inclusion. Professionals need to be aware of children's cognitive learning characteristics [8] and create learning experiences that build independent life skills. 


\subsection{Pre-Service Teacher Knowledge of Autism Spectrum Disorder}

Studies show that Romanian and Greek teachers are not always aware of and equipped with the necessary knowledge and skills to manage social interactions and behavioural challenges in students with ASD [9-11]. Educating children with ASD in Romanian and Greek inclusive settings is characterised by strong resistance from teachers $[10,12]$. We believe this is due mainly to a lack of knowledge in managing the classroom needs of students with ASD and insufficient supporting services for general teachers.

Romania has a painful past in educating and caring for young people with ASD. Before 1990 (during the communist regime), children and adults with disabilities were little known and even intentionally hidden. Children with severe disabilities, including those with severe ASD, were institutionalised in large residential centres with more than 350 residents [13]. After 1990, fundamental changes took place in Romania in improving the lives of children with disabilities. Students with special educational needs from mainstream schools started receiving support; after 1995, their inclusion was regulated by the National Education Law [14]. National and international non-governmental organisations played an essential role in this change. Nonetheless, teachers hold negative attitudes towards including students with ASD in mainstream schools [9], and knowledge and resources regarding ASD are limited [10]. Empirical evidence also shows that teachers may be ambivalent towards involving students with ASD in classroom activities [15].

Compared to Romania, Greece has a more positive approach. The education of children with disabilities has been ensured by law since the early 1980s. Although Romania and Greece are part of the European Union and present similarities regarding inclusive education legislation, only Greece is a member of the European Agency for Special Needs and Inclusive Education, aiming to optimise inclusive education policies in members [16]. This affiliation may be associated with faster progress in inclusive Greek education. In light of new international policies regarding persons with disabilities [17], schooling in Greece has changed over the years, and many students with ASD are present in classrooms [18]. Benchmarking analysis of education systems in the two countries revealed other similarities. For example, despite the openness to diversity of the Greek education system, the inclusion of children with disabilities in mainstream schools is still hard [19].

Both countries organise training for teachers as part of the professional development of employees in education, but there is no mechanism for assessing the acquired knowledge. For mainstream classroom teachers from Romanian and Greek schools, it is still difficult to identify students with ASD (e.g., in Romania, some families do not disclose their child's diagnosis due to fear of stigma [20]), to assess their learning potential and barriers, and, ultimately, to provide a meaningful and qualitative educational intervention. Ideally, all of this requires an educational team that includes psychologists, support teachers, special educators, speech and language therapists, and social workers. In this sense, there is a shortage of necessary professionals aiding mainstream schoolteachers. In contrast, much has been done to advance the teaching staff in Greece (e.g., OEPEK establishment). Therefore, a comparative study on the specific needs of teachers from both countries brings relevant data on teachers' needs, learning gaps, and different mechanisms implemented by teachers and educational communities to support students with ASD and create inclusive classrooms.

Other countries have reported similar situations concerning preparing teachers for including ASD students in their mainstream classrooms [21]. For example, teachers in Florence report low levels of training [22]. In Spain, teachers generally have a positive attitude towards inclusion, but this depends on training and contact with students with special educational needs [23]. Lack of training, diversity, and a large number of students in the class enhance the teachers' difficulties in monitoring and providing one-on-one intervention for every challenges [24]. Therefore, it would impact teachers' efficiency in teaching and the learning outcomes of students with ASD and other students.

Learning is ensured by teachers' willingness to undertake targeted professional training in ASD and adjust school discipline $[25,26]$. In Croatia, North Macedonia, and Poland, a lack of adequate preparation in evidence-based practices for ASD students were reported, 
including inadequate training during initial teacher education and lack of updated knowledge on ASD [27]. Mostly, mainstream teachers require techniques to assess and address challenging behaviours of children with ASD [28]. A meta-analysis of 23 studies on training evaluation for teachers working with ASD students synthesised some crucially important directions of teachers' training demands for behavioural interventions to improve students' communication and social interaction [29]. However, teachers' needs in these critical domains remained low, confirming the need for appropriate teacher education regarding theory, relevant practical strategies, and coaching to enable them with the necessary tools to work with children with ASD. Based on the literature review, mainstream teachers prevailing need to serve children with ASD appears to be critical. Training needs identified by some studies [30] focus on behaviour management and positive behaviour support, and evidence-based instructional strategies for children with ASD.

In summary, investing in teachers' training impacts education quality and potentially teachers' satisfaction with life [31]. Empowering teachers working with children with ASD is crucial because they are more vulnerable to teacher attrition [32]. As a result, they might experience minor personal accomplishments and have lower efficacy [33]. Lack of appropriate training and preparation in evidence-based practices for students with ASD and sparse expert resources negatively impact teachers' confidence [34-36]. The contradiction between working requirements and initial training knowledge and difficulty in using mobile equipment [24,37] are also prevalent factors that make teaching more provoking for mainstream teachers. Apps seem to be easier to use, and their development in the past years has helped parents and teachers in the recovery process of children with ASD [38].

\subsection{E-Learning Training Programmes for Teacher Education in ASD}

The professional development of teachers has increasingly gained greater importance [39], and the adoption of online training and appropriate strategies is vital [40]. Developing teachers' self-efficacy starts in pre-service training, and it is recommended to be improved by providing continuing adequate training and mentorship programmes [41]. Best practices and quick solutions to address teachers' immediate teaching and learning needs might be solved by developing online training programmes because of their potential in teachers' professional development [40]. In the global COVID-19 pandemic and the shift to remote teaching, teachers need support and the development of effective training programmes and online network training platforms [42,43].

Online courses are provided asynchronously and synchronously, implying that teachers have enough confidence in their technical skills to navigate the online environment. On the other hand, teachers need effective professional development to learn how to use and integrate technology into instruction [44]. Therefore, it is essential to expand specific professional development training to empower teachers to overcome the challenges of ICT-based instruction [42]. However, teaching in the digital age creates opportunities and challenges for teachers' training providers.

Online training designed for teachers' professional development on ASD implies video and slide presentations and exercises in creating structured teaching material [45]. The process involves several stages based on continuous course redesigning based on the Universal Design for Learning (UDL) framework to improve the learning experiences of students and teachers [46]. Research on professional development training suggests that online training can update teachers' knowledge and skills despite some uncertainties in their ICT-use skills by designing hands-on, learner-centred, and collaborative technology training activities $[47,48]$.

\subsection{Research Aim}

Both Romania and Greece are collectivistic societies, with slower development in education for people with ASD. The resistance in educating children with ASD in Romanian and Greek mainstreams schools $[9,49]$ and the behavioural challenges that children with 
ASD bring to classrooms for their teachers, primarily due to this disorder's core symptoms, impose the crucial need to address the issue of providing modules on evidence-based practices for students with ASD in pre-service teacher training. However, to the best of our knowledge, a survey on the training needs of professionals working with children with ASD in these countries has not been performed. Therefore, this study aimed to compare data from Greece and Romania regarding ASD knowledge and training needs of professionals involved in educating students with ASD. The study had the following research questions: (1) What is the ASD knowledge level in Romania and Greece? (2) What are the main training needs of professionals working with students with ASD? (3) Given the growing importance of ICT-based instruction in education, do professionals in Romania and Greece need training in this regard?

\section{Methods and Materials}

\subsection{Participants and Design}

In order to find out what the needs are for ASD education in professionals working with ASD students, we used a cross-sectional study design. We asked specialists from two different countries (i.e., Greece and Romania) to answer a survey on the topic. A convenience sampling procedure was employed. We included participants based on the following criteria: (1) adults that were at least 20 years old (the minimum age that would allow them to have gained professional formal autism training at an undergraduate level) and (2) adults working in a professional role with at least one child diagnosed with autism. We excluded relatives (e.g., parents, grandparents) of children with autism. As a result, 475 Romanians (470 females and 5 males) and 211 Greek specialists (180 females, 31 males) participated in this research. Most participants in both countries were teachers (mainstream, special school, kindergarten) and had over five years of working experience in education. A total of $36 \%$ of Greek respondents and $43 \%$ of Romanian respondents had not taken any course on ASD (despite interacting with these students), and $45 \%$ of respondents from each country had taken private courses. The detailed demographic data for both countries are displayed in Table 1.

Table 1. Participants' socio-demographic data.

\begin{tabular}{ccc}
\hline Variables & Greece (N = 211) & Romania (N = 475) \\
\hline Age range & & $7 \%$ \\
$20-25$ years old & $10 \%$ & $25 \%$ \\
$26-35$ years old & $38 \%$ & $68 \%$ \\
Over 35 years old & $52 \%$ & \\
Profession & & $3 \%$ \\
Kindergarten educator & $10 \%$ & $7 \%$ \\
Support teacher & $11 \%$ & $16 \%$ \\
Special education teacher & $19 \%$ & $23 \%$ \\
Mainstream education teacher & $22 \%$ & $13 \%$ \\
School counsellor & $3 \%$ & $3 \%$ \\
Speech therapist & $16 \%$ & $20 \%$ \\
Psychologist & $8 \%$ & $6 \%$ \\
ABA therapist & $1 \%$ & $9 \%$ \\
Other (occupational therapist, social & $10 \%$ & \\
worker, head of school) & & $44 \%$ \\
Working institution & & $25 \%$ \\
Public school & $34 \%$ & $11 \%$ \\
Special school & $4 \%$ & $13 \%$ \\
Private practice & $4 \%$ & $5 \%$ \\
Kindergarten & $47 \%$ & $2 \%$ \\
pthychiatry hospital) & $5 \%$ &
\end{tabular}


Table 1. Cont.

\begin{tabular}{ccc}
\hline Variables & Greece $(\mathbf{N}=\mathbf{2 1 1})$ & Romania $(\mathbf{N}=\mathbf{4 7 5})$ \\
\hline Professional experience & & $3 \%$ \\
$0-1$ year & $14 \%$ & $14 \%$ \\
$1-3$ years & $11 \%$ & $10 \%$ \\
$3-5$ years & $12 \%$ & $23 \%$ \\
$5-10$ years & $16 \%$ & $50 \%$ \\
Over 10 years & $47 \%$ & $43 \%$ \\
Previous autism education courses & & $45 \%$ \\
No courses & $36 \%$ & $11 \%$ \\
Private courses & $45 \%$ & $1 \%$ \\
\hline
\end{tabular}

\subsection{Measures}

All the measures were compiled into one questionnaire, then translated and applied in the Romanian and Greek languages. We devised two self-reported measures, one for assessing ASD knowledge (based on the core symptoms, the most prevalent challenges reported in the literature, and innovative teaching technologies) and the other for assessing ASD training needs. We chose to develop these instruments because they link the exact ASD knowledge dimensions to the training needs, serving the aim of this study.

\section{(a) ASD Knowledge Scale}

The self-perceived level of knowledge regarding ASD was assessed with a 6-item scale devised by the authors. The items inquired about how much the participants knew about the following topics: the DSM-IV/DSM-5 diagnostic criteria for ASD, the use of assessment tools for diagnosing conduct disorders, methods for behaviour management, methods to improve communication, strategies for meeting the needs of a student with ASD in the classroom, and innovative teaching technologies. The answers were scored on a 4-point Likert scale, from 1 ("I do not know") to 4 ("I know a lot/I am an expert"). An example of an item is "Do you know the symptoms of autism that are described in DSM-IV or DSM-5 manual?" The total score was the sum of all the answers. A bigger score reflected more ASD knowledge. The Cronbach's alpha internal consistency indices for the Romanian and Greek versions of the scale had good values $\left(\alpha_{\text {Romania }}=0.87, \alpha_{\text {Greece }}=0.85\right)$.

\section{(b) ASD Training Needs Scale}

The perceived level of training needs was investigated with a 7-item scale developed by the authors. The items referred to how helpful it would be for the participants to receive training on the topics addressed in the ASD knowledge scale. Additionally, they were asked how helpful it would be to access an e-learning platform with courses and materials addressing the topics in the knowledge scale. The answers were scored on a 4-point Likert scale, from 1 ("Not helpful") to 4 ("Very helpful"). An example of an item is "How helpful would it be for you to attend a course on improving communication skills in students with ASD?" The total score was obtained by summing up all the answers, and a bigger score indicated higher training needs. The Cronbach's alpha indices for the Romanian and Greek versions of the scale had good values $\left(\alpha_{\text {Romania }}=0.82, \alpha_{\text {Greece }}=0.84\right)$.

(c) Socio-demographic Data

We collected socio-demographic information relevant for the study (i.e., gender, age, profession, working institution, years of experience in the field, previous ASD courses).

\subsection{Procedure}

Between October and November 2018, the first version of the questionnaire was developed by a panel of four experts in special education and psychology (PhD and 
postdoc level). In addition, the questionnaire was translated into the Romanian and Greek languages and piloted in December 2018, using 10 ASD professionals in each state.

Between January and March 2019, the final version of the questionnaire was inserted into Google Forms and shared online with the network of professionals in autism in each country.

The participants read and agreed to an informed consent explaining the purpose of the questionnaire, the risks, and the benefits of proving the information. They could withdraw from the survey when they saw fit, without consequences. Participation was voluntary, and no incentives were offered. Since the study was part of a larger project, some people provided their email addresses to receive news regarding the project.

The study was conducted according to the guidelines of the Declaration of Helsinki. Furthermore, this research received ethical approval from the Ethics Committee of the University of Bucharest.

\subsection{Data Analysis}

We analysed the data with IBM SPSS Statistics for Windows, version 25. First, we reported descriptive statistics of the main variables (means, standard deviations, Spearman's rho correlation, frequencies). We probed into the normality of the data with the Shapiro-Wilk test. When the $p$-value of the test was less than 0.05 , the null hypothesis for normally distributed data was rejected. Second, we employed principal component analysis to investigate the internal reliability of the devised measures. To test for the suitability of the data for structure detection, we used Barlett's test of sphericity and the Kaiser-Meyer-Olkin index. Third, to determine whether the general differences between Greek and Romanian respondents in ASD knowledge and training needs were statistically significant, we conducted a series of Mann-Whitney U tests for independent samples. The tests were considered statistically significant when the $p$-value was under 0.05 .

\section{Results}

\subsection{Exploratory Factor Analyses for the Measures Used in the Study}

The overall results of the principal component analyses performed on the samples from Greece and Romania show that the items of the scales developed by the authors explained a fair amount of construct variance (between 51.6 and 62.7\%) and mainly had high loadings. The analyses provided evidence of the measures' internal reliability. Specifically, on the ASD knowledge scale, the Barlett's tests had significant values $(p<0.001)$, the KMO indices had values above 0.83 , and the factor loadings ranged between 0.500 and 0.897 . We obtained similar results for the ASD training needs scale, with KMO indices between 0.82 and 0.83 and factor loadings between 0.458 and 0.846 . For the detailed analyses, please consult Supplementary Material 1 (Tables S1 and S2).

\subsection{Descriptive Statistics for Greece and Romania}

The main descriptive statistics and the correlation between ASD knowledge and training needs for each country are displayed in Table 2. The Shapiro-Wilk test showed that the null hypothesis was rejected; therefore, we used the Spearman's rho non-parametric correlation test. ASD knowledge inversely correlated with ASD training needs, but the correlation was not significant.

Table 2. Main descriptive statistics.

\begin{tabular}{cccc}
\hline Variable & Indicator & Greece $\mathbf{( N = 2 1 1 )}$ & Romania $(\mathbf{N}=\mathbf{4 7 5})$ \\
\hline \multirow{2}{*}{ ASD knowledge } & Mean (SD) & $15.2(4.22)$ & $13.7(3.88)$ \\
& Shapiro-Wilk $p$ & 0.004 & $<0.001$ \\
ASD training needs & Mean (SD) & $26(2.98)$ & $27.2(1.84)$ \\
& Shapiro-Wilk $p$ & $<0.001$ & $<0.001$ \\
& Spearman's rho $(p$-value $)$ & $-0.13(0.053)$ & $-0.07(0.110)$ \\
\hline
\end{tabular}


The means and frequency statistics for each question are summarised in Table S3 from the Supplementary Materials. We believe that these descriptive results may be helpful to those who are building learning programmes for professionals working with autistic students, as they show the strengths and weaknesses of the participants' knowledge and their most stringent training needs.

Regarding Greece, more than half of the participants knew a fair amount or a lot about the diagnostic criteria of autism, about improving communication skills in autism, and about strategies to meet their classroom needs. At the same time, less than $50 \%$ declared that they knew a fair amount or a lot about using models/assessment tools, managing problem behaviours, and innovative teaching technologies for autism. Between 64 and $88 \%$ of Greeks believed that courses on all these topics would be very helpful for them. In terms of means, Greek respondents seemed to know most about ASD symptoms $(M=3.27$, $S D=0.97)$ and least about ASD innovative teaching technologies $(M=1.83, S D=0.81)$. The biggest mean on training needs was on the e-learning platform item $(M=3.88, S D=0.34)$, showing the necessity for such a learning tool.

Concerning Romania, over $50 \%$ of respondents a fair amount or a lot about the diagnostic criteria for autism, whereas less than $50 \%$ knew about the other areas covered by the scale. The training need for all the assessed topics was high, as between 89 and 93\% of the Romanian participants said they would find it very helpful to receive courses about the investigated areas. Regarding the means, the situation in Romania is similar to Greece's: The highest level of knowledge was on ASD symptoms $(M=2.74, S D=0.85)$ and the lowest level on ASD teaching technologies $(M=1.87, S D=0.80)$. The highest means on training needs were recorded for conduct assessment $(M=3.90, S D=0.37)$, strategies for dealing with behaviour problems $(M=3.90, S D=0.36)$, and communication skills training $(M=3.90, S D=0.36)$.

\subsection{Differences Regarding ASD Knowledge}

A Mann-Whitney test indicated that Greeks $(M d n=15)$ outperformed Romanians $(M d n=14)$ on the overall ASD knowledge scale $(U=39703, p<0.001)$. We obtained similar results for the following items of the scale: symptoms of autism, managing problem behaviours, communication skills, and meeting the student's classroom needs. Both countries reported the lowest knowledge level on the innovative teaching technology item. For details, consult Table 3.

Table 3. Differences between Greece and Romania regarding ASD knowledge.

\begin{tabular}{lcccc}
\hline & Median Greece & Median Romania & U & $p$ \\
\hline \multicolumn{1}{c}{ ASD knowledge } & 15 & 14 & 39703 & $<0.001$ \\
1. Symptoms & 4 & 3 & 32466 & $<0.001$ \\
2. Conduct assessment & 2 & 2 & 45785 & 0.058 \\
3. Problem behaviour & 2 & 2 & 44859 & 0.020 \\
4. Communication & 3 & 2 & 38702 & $<0.001$ \\
5. Classroom needs & 3 & 2 & 40541 & $<0.001$ \\
6. Teaching tech & 2 & 2 & 48473 & 0.463 \\
\hline
\end{tabular}

\subsection{Differences Regarding ASD Training Needs}

Regarding ASD general training needs, the Mann-Whitney test showed that Romania $(M d n=28)$ had a higher training need $(U=35556, p<0.001)$ than Greece $(M d n=27)$. The data support the same results on training regarding autism symptoms, conduct assessment, problem behaviour management, communication skills, classroom needs, and teaching technologies for ASD. The need for an e-learning platform was similarly high in both countries. All the results are summarised in Table 4. 
Table 4. Differences between Greece and Romania regarding ASD training needs.

\begin{tabular}{lcccc}
\hline & Mean/Median Greece & Mean/Median Romania & U & $p$ \\
\hline \multicolumn{1}{c}{ ASD training needs } & $25.98 / 27$ & $27.22 / 28$ & 35556 & $<0.001$ \\
1. Symptoms & $3.42 / 4$ & $3.87 / 4$ & 36930 & $<0.001$ \\
2. Conduct assessment & $3.68 / 4$ & $3.90 / 4$ & 41677 & $<0.001$ \\
3. Problem behaviour & $3.78 / 4$ & $3.92 / 4$ & 44121 & $<0.001$ \\
4. Communication & $3.72 / 4$ & $3.90 / 4$ & 42716 & $<0.001$ \\
5. Classroom needs & $3.70 / 4$ & $3.88 / 4$ & 43363 & $<0.001$ \\
6. Teaching tech & $3.80 / 4$ & $3.89 / 4$ & 46471 & 0.004 \\
7. E-learning platform & $3.88 / 4$ & $3.86 / 4$ & 49275 & 0.511 \\
\hline
\end{tabular}

\section{Discussion}

More and more schools in Europe face an influx of children with autism. Data on the prevalence of ASD show that this spectrum of disorders is becoming more common. A metastudy published in 2012 reported an overall prevalence of 1 in 160 children [50], whereas the US Centers for Disease Control and Prevention indicated an increase in prevalence over time-from 1 in 69 children in 2012 to 1 in 44 children in 2018 [51]. Furthermore, the prevalence rate of school-aged individuals (i.e., 6-17 years) diagnosed with ASD has significantly increased to 1 in 50 [52]. Along with the rise of autism prevalence among children, the number has increased pragmatically in public schools, so knowledge of the disorder and methods of classroom approaches have become critical topics. As such, this paper aimed to investigate the ASD knowledge and training needs of Greek and Romanian specialists working with students with ASD. Cross-cultural differences in the interpretation of the child's educational needs highlighted that improvements in the training of specialists in both cultures are needed. In addition, knowledge of another cultures' educational experiences and how they care for children with ASD can offer both countries insight into their practices and ways to improve their education system.

\subsection{ASD Knowledge}

Concerning overall ASD knowledge, Greek respondents had a better level of knowledge than their Romanian counterparts. The differences were significant regarding ASD symptoms, managing problem behaviours, communication skills, and meeting the students' classroom needs. This result can be explained by the difference in education quality in these countries. The World Population Review reported Greece as being in the 26th position and Romania in the 40th in worldwide education rankings for 2020 [53].

In both countries, the lowest level of knowledge was signalled in innovative teaching technologies for ASD, which highlights a joint gap in the training programmes available in both countries. Online education has become a mainstream way of education. It is continually increasing because the advantages of online-technology-based training are its independence and the time and place flexibility in interaction with the content and with others [54]. The flexibility and convenience of e-learning programmes provide an effective way for teachers to attain professional development [37]. Online training has been prevalent in professional development and support and has been proven to raise teachers self-efficacy and boost teaching practices [42]. One of the disadvantages of online training is some challenges teachers still might have regarding ICT skills, discouraging them from adopting new teaching technologies [55].

At the same time, the descriptive results of this analysis of needs suggest some knowledge about autism symptoms among professionals from Greece and Romania. The situation is encouraging because the level of knowledge has increased in recent years [56], and the attitude and perception of children with autism have improved. On the other hand, the belief that the intellectual capacity is fixed and that students with ASD have intellectual challenges was relatively high for Romanian and Greek respondents [57]. 


\subsection{ASD Training Needs}

Overall, the training needs were high in both countries. From a statistical point of view, Romanian respondents had higher ASD training needs than Greek professionals, which was expected considering the results on ASD knowledge. Specifically, Romanians had higher training needs in conduct assessments, managing problem behaviours, teaching communication skills, and meeting the students' classroom needs. Even so, the need to be trained using a complex e-learning platform with multiple theoretical and practical materials was similarly high in both countries.

On the one hand, it is gratifying that specialists want to take courses on ASD, but on the other hand, the results indicate gaps in the declarative and procedural knowledge of specialists. The situation is even more worrying since most participants had over three years of work experience. This also suggests that the national education curriculum for teachers and other specialists addresses, to a small extent, the topic of ASD. The statement was backed up even by participants who claimed that if they took courses on ASD, they were mainly private. Less than $20 \%$ of the participants had taken ASD courses at the master's or PhD level, reinforcing that the national education system is faulty in this domain in both countries. The results show that Romanian and Greek teacher training is still lacking in evidence-based practices for students with ASD. At the same time, other countries (e.g., USA) receive more training on specific practices in working with ASD during preservice teacher training [36].

We know by now that communication deficits are one of the core symptoms of ASD. However, the range of impairment is extensive, from completely non-verbal or simplistic language to mild difficulties in using language to accomplish social goals [58]. This is why teachers need multiple tools to tackle the diversity of manifestations, and the results show a great need for training in this area. In addition, research findings show an interest in the collaborative model of training, exchanging good practices in teaching students with ASD and opportunities to reflect on exchanges [59].

Students with ASD face multiple academic challenges when attending regular or inclusive education settings. First, it may be hard for them to engage in classroom tasks or assignments due to environmental distractors, attention deficits, lack of motivation, or conduct disorders [60]. Second, it may be challenging to learn new material, particularly lessons that require mental flexibility and high processing speed [61]. The third challenge comes from understanding, executing, and finishing classroom assignments [62]. All these challenges affect the learning process for the students with ASD and their social integration. Therefore, the requirement to assess, understand, and respond to autistic students' classroom needs becomes a priority for teachers. The evidence from this survey supports this claim, as most teachers need help to improve classroom support for their students with ASD.

As the participants reported a high need for an e-learning platform dedicated to ASD, a discussion on the best practices in this field is necessary. For example, in online training, providing videos to accompany text instructions and space for case study discussions and activities is necessary to facilitate reflection on the learning process and enhance the transfer of the outcomes [46]. Those recommendations are helpful because working with students with ASD implies developing unique techniques and trying several techniques until the appropriate one for a specific child is identified, so training activities should be designed to facilitate case study reflections. In addition, an e-learning platform would provide valuable supplementary learning materials, interaction and practice opportunities, and ways of assessing their learning outcomes. Good platform models have been identified in the literature to help professionals and parents optimise their teaching process and interact with students with ASD [63-66]. Based on these models, future products can be improved by addressing the topics identified in this study.

Additionally, some studies have shown that socio-emotional development is underrepresented in existing teaching applications [38]. As such, future ICT-based instruction 
products should cover this shortcoming. All these recommendations can help design a good e-learning platform, meeting the needs of both professionals and students with ASD.

Technology usage is one of the strengths that people with ASD possess [67]. Therefore, it is only natural to think about implementing teaching technologies (such as tablet applications, interactive boards, multimedia academic programmes, teaching robots) in the classroom with technology-prone students. However, as this study shows, the teachers grew up in a less technology-rich environment (especially those with many years of experience) and may not have the proper knowledge or skills. Moreover, innovative teaching technologies are sometimes expensive and less common, but this is a challenge that the COVID-19 pandemic is probably changing as we speak.

\subsection{Limitations}

So far, the strengths and practical implications of this study's results have been pinpointed. However, to properly interpret these findings, it is necessary to discuss the main limitations. Given the convenience sampling procedure, we cannot generalise the results across the countries, and the cross-sectional design does not allow causal inferences. Furthermore, the online data collection procedure may have biased some results, as only professionals who use the Internet groups could see the invitation to participate in the study. As a result, we expect to find even more significant ASD knowledge and training gaps regarding innovative teaching technologies in professionals who do not often use the Internet. Nevertheless, the sample sizes were adequate, and the results can raise awareness of the need for digital learning resources for professionals working with students with ASD.

Supplementary Materials: The following supporting information can be downloaded at: https: / / www.mdpi.com/article/10.3390/su14052986/s1, Tables S1 and S2: Exploratory factor analyses for the devised measures; Table S3: Answer frequency for ASD knowledge and training needs.

Author Contributions: Conceptualization, R.F. and C.K.S.-D.; Methodology, R.F. and C.I.I.; Software, C.I.I.; Formal Analysis, C.I.I.; Investigation, R.F., C.D. and C.I.I.; Data Curation, C.I.I.; WritingOriginal Draft Preparation, R.F., C.D. and C.I.I.; Writing-Review \& Editing, R.F., C.D. and C.I.I.; Visualization, all authors; Supervision, C.K.S.-D.; Project Administration, C.K.S.-D. and R.F.; Funding Acquisition, C.K.S.-D. All authors have read and agreed to the published version of the manuscript.

Funding: This work was funded by the Erasmus+ Program, Key Action 202 (project number 2018-1EL01-KA202-047738).

Institutional Review Board Statement: The study was conducted according to the guidelines of the Declaration of Helsinki, and approved by the Ethics Committee of University of Bucharest number 33/02.07.2021.

Informed Consent Statement: Informed consent was obtained from all subjects involved in the study.

Data Availability Statement: The data presented in this study are available on request from the corresponding author.

Conflicts of Interest: The authors declare no conflict of interest.

\section{References}

1. American Psychiatric Association. The Diagnostic and Statistical Manual of Mental Disorders, 5th ed.; (DSM-5); American Psychiatric Publishing: Washington, DC, USA, 2013.

2. Webber, J.; Scheuermann, B. Educating Students with Autism: A Quick Start Manual; PRO-ED: Austin, TX, USA, 2008.

3. Merriam-Webster. Available online: https://www.merriam-webster.com/dictionary/communication (accessed on 24 February 2022).

4. National Institute on Deafness and Other Communication Disorders. Available online: https://www.nidcd.nih.gov/health/ autism-spectrum-disorder-communication-problems-children (accessed on 24 February 2022).

5. Williams, D.L.; Siegel, M.; Mazefsky, C.A.; for the Autism and Developmental Disorders Inpatient Research Collaborative (ADDIRC). Problem Behaviors in Autism Spectrum Disorder: Association with Verbal Ability and Adapting/Coping Skills. J. Autism Dev. Disord. 2018, 48, 3668-3677. [CrossRef] [PubMed] 
6. Yorke, I.; White, P.; Weston, A.; Rafla, M.; Charman, T.; Simonoff, E. The Association between Emotional and Behavioral Problems in Children with Autism Spectrum Disorder and Psychological Distress in Their Parents: A Systematic Review and Meta-analysis. J. Autism Dev. Disord. 2018, 48, 3393-3415. [CrossRef] [PubMed]

7. Von der Embse, N.; Brown, A.; Fortain, J. Facilitating Inclusion by Reducing Problem Behaviors for Students with Autism Spectrum Disorders. Interv. Sch. Clin. 2011, 47, 22-30. [CrossRef]

8. Klintwall, L.; Gillberg, C.; Bölte, S.; Fernell, E. The Efficacy of Intensive Behavioral Intervention for Children with Autism: A Matter of Allegiance? J. Autism Dev. Disord. 2012, 42, 139-140. [CrossRef] [PubMed]

9. Walker, G. Inclusive education in Romania: Policies and practices in post-Communist Romania. Int. J. Incl. Educ. 2010, 14, 165-181. [CrossRef]

10. Pasco, G.; Clark, B.; Dragan, I.; Kalambayi, F.; Slonims, V.; Tarpan, A.K.; Wittemeyer, K. A training and development project to improve services and opportunities for social inclusion for children and young people with autism in Romania. Autism 2014, 18, 827-831. [CrossRef]

11. Anastasiou, D.; Polychronopoulou, S. Identification and Overidentification of Specific Learning Disabilities (Dyslexia) in Greece. Learn. Disabil. Q. 2009, 32, 55-69. [CrossRef]

12. De Boer, A.; Pijl, S.J.; Minnaert, A. Regular primary schoolteachers' attitudes towards inclusive education: A review of the literature. Int. J. Incl. Educ. 2011, 15, 331-353. [CrossRef]

13. UNICEF. Available online: https://www.unicef.org/romania/topics/children-disabilities (accessed on 24 February 2022).

14. Romanian Ministry of Education. Available online: http:/ /www.cnfis.ro/wp-content/uploads/2012/08/Legea-Invatamantuluinr.-84_1995.pdf (accessed on 24 February 2022).

15. Roman, A.F.; Pota, E. Teachers' Attitude on the Development of the Socio-Emotional Competencies at Children with Autism. J. Plus Educ. 2018, XXI, 331-336.

16. European Agency for Special Needs and Inclusive Education. Available online: https://www.european-agency.org/countryinformation (accessed on 24 February 2022).

17. United Nations. Available online: https://www.un.org/development/desa/disabilities/convention-on-the-rights-of-personswith-disabilities / convention-on-the-rights-of-persons-with-disabilities-2.html (accessed on 24 February 2022).

18. Mavropoulou, S.; Padeliadu, S. Greek Teachers' Perceptions of Autism and Implications for Educational Practice: A Preliminary Analysis. Autism 2000, 4, 173-183. [CrossRef]

19. Pappas, M.A.; Papoutsi, C.; Drigas, A.S. Policies, Practices, and Attitudes toward Inclusive Education: The Case of Greece. Soc. Sci. 2018, 7, 90. [CrossRef]

20. Iacob, C.I. Improving Communication in Children with ASD: The Family's Role. In Interventions for Improving Adaptive Behaviors in Children with Autism Spectrum Disorders; IGI Global: Hershey, PA, USA, 2022; pp. 250-265.

21. Lopes, J.A.; Oliveira, C. Teacher and school determinants of perceived classroom discipline: A multilevel analysis of TALIS 2013. Learn. Environ. Res. 2021, 1-18. [CrossRef]

22. Del Pilar Gallardo-Montes, C.; Caurcel Cara, M.J.; Rodríguez Fuentes, A.; Capperucci, D. Formación y uso de TIC en aulas con estudiantes con autismo. Experiencia con docentes de Florencia. Ann. Online Della Didat. E Della Form. Docente 2021, 13, 49-67. [CrossRef]

23. Lacruz-Pérez, I.; Sanz-Cervera, P.; Tárraga-Mínguez, R. Teachers' Attitudes toward Educational Inclusion in Spain: A Systematic Review. Educ. Sci. 2021, 11, 58. [CrossRef]

24. Grey, I.M.; Honan, R.; McClean, B.; Daly, M. Evaluating the effectiveness of teacher training in Applied Behaviour Analysis. J. Intellect. Disabil. 2005, 9, 209-227. [CrossRef]

25. Courtemanche, A.B.; Turner, L.B.; Molteni, J.D.; Groskreutz, N.C. Scaling up Behavioral Skills Training: Effectiveness of LargeScale and Multiskill Trainings. Behav. Anal. Pract. 2020, 14, 36-50. [CrossRef]

26. Soares, E.E.; Bausback, K.; Beard, C.L.; Higinbotham, M.; Bunge, E.L.; Gengoux, G.W. Social Skills Training for Autism Spectrum Disorder: A Meta-analysis of In-person and Technological Interventions. J. Technol. Behav. Sci. 2021, 6, 166-180. [CrossRef]

27. Šegota, N.L.; Lištiaková, I.L.; Stošić, J.; Kossewska, J.; Troshanska, J.; Nikolovska, A.P.; Cierpiałowska, T.; Preece, D. Teacher education and confidence regarding autism of specialist primary school teachers. Eur. J. Spéc. Needs Educ. 2022, 37, 1-14. [CrossRef]

28. Wei, L.S.; Yasin, M.H.M. Teacher Training to Increase Teacher's Competency in Teaching Autism Child. J. ICSAR 2017, 1, 1-5. [CrossRef]

29. Alexander, J.L.; Ayres, K.M.; Smith, K.A. Training Teachers in Evidence-Based Practice for Individuals with Autism Spectrum Disorder: A Review of the Literature. Teach. Educ. Spéc. Educ. J. Teach. Educ. Div. Counc. Except. Child. 2014, 38, 13-27. [CrossRef]

30. Rakap, S.; Balikci, S.; Kalkan, S. Teachers' knowledge about autism spectrum disorder: The case of Turkey. Turk. J. Educ. 2018, 7, 169-185. [CrossRef]

31. Hattie, J. Visible Learning for Teachers: Maximising Impact on Learning; Routledge: London, UK; New York, NY, USA, 2012.

32. Göktürk, Ş.; Tülübaş, T.; Bozoğlu, O. A motivational perspective on teacher retention in special education: A critical case from Turkey. Educ. Res. Policy Pract. 2021, 20, 63-78. [CrossRef]

33. Scott, S.B. Factors Influencing Teacher Burnout and Retention Strategies, Honors Research Projects; The University of Akron: Akron, OH, USA, 2019. 
34. Syriopoulou-Delli, C.K.; Cassimos, D.C.; Polychronopoulou, S.A. Collaboration between teachers and parents of children with ASD on issues of education. Res. Dev. Disabil. 2016, 55, 330-345. [CrossRef]

35. Finlay, C.; Kinsella, W.; Prendeville, P. The professional development needs of primary teachers in special classes for children with autism in the republic of Ireland. Prof. Dev. Educ. 2019, 1-21. [CrossRef]

36. Hsiao, Y.-J.; Petersen, S.S. Evidence-Based Practices Provided in Teacher Education and In-Service Training Programs for Special Education Teachers of Students with Autism Spectrum Disorders. Teach. Educ. Spéc. Educ. J. Teach. Educ. Div. Counc. Except. Child. 2019, 42, 193-208. [CrossRef]

37. Peng, D. Mobile-Based Teacher Professional Training: Influence Factor of Technology Acceptance. In Foundations and Trends in Smart Learning; Chang, M., Popescu, E., Kinshuk, Chen, N.-S., Jemni, M., Huang, R., Spector, J.M., Sampson, D.G., Eds.; Lecture Notes in Educational Technology; Springer Singapore: Singapore, 2019; pp. 161-170. [CrossRef]

38. Montes, C.D.P.G.; Fuentes, A.R.; Cara, M.J.C. Apps for people with autism: Assessment, classification and ranking of the best. Technol. Soc. 2021, 64, 101474. [CrossRef]

39. Del Río, G.N.B. A useful framework for teacher professional development for online and blended learning to use as guidance in times of crisis. Educ. Technol. Res. Dev. 2021, 69, 7-9. [CrossRef]

40. Gogus, A. Shifting to digital: Adoption and diffusion. Educ. Technol. Res. Dev. 2021, 69, 11-16. [CrossRef]

41. Yada, A.; Tolvanen, A.; Malinen, O.-P.; Imai-Matsumura, K.; Shimada, H.; Koike, R.; Savolainen, H. Teachers' self-efficacy and the sources of efficacy: A cross-cultural investigation in Japan and Finland. Teach. Teach. Educ. 2019, 81, 13-24. [CrossRef]

42. Kim, J.; Pak, S.; Cho, Y.H. The Role of Teachers' Social Networks in ICT-Based Instruction. Asia Pac. Educ. Res. 2021, 1-10. [CrossRef]

43. Stefaniak, J.; Luo, T.; Xu, M. Fostering pedagogical reasoning and dynamic decision-making practices: A conceptual framework to support learning design in a digital age. Educ. Technol. Res. Dev. 2021, 69, 2225-2241. [CrossRef]

44. Dalinger, T.; Asino, T.I. Design of an Instrument Measuring P-12 Teachers' Cognitive Load and Intent to Adopt Technology. TechTrends 2021, 65, 288-302. [CrossRef]

45. Syriopoulou-Delli, C.K.; Sarri, K. Video-based instruction in enhancing functional living skills of adolescents and young adults with autism spectrum disorder and their transition to independent living: A review. Int. J. Dev. Disabil. 2021, 1-12. [CrossRef]

46. Cai, Q.; Robinson, D. Design, Redesign, and Continuous Refinement of an Online Graduate Course: A Case Study for Implementing Universal Design for Learning. J. Form. Des. Learn. 2021, 5, 16-26. [CrossRef]

47. Unger, K.L.; Tracey, M.W. Examining the factors of a technology professional development intervention. J. Comput. High. Educ. 2013, 25, 123-146. [CrossRef]

48. Wagner, R.; Piovesan, S.; Passerino, L.; De Lima, J.V.; De Castro Lozano, C. MOOCs of Inclusive Technology in Teacher Education for Vocational Education. Creative Educ. 2015, 6, 1832-1840. [CrossRef]

49. Syriopoulou-Delli, C. Parallel Support with the Use of Technology for Individuals with Autism Spectrum Disorders; Grigoris Plc.: Athens, Greece, 2021.

50. Elsabbagh, M.; Divan, G.; Koh, Y.-J.; Kim, Y.S.; Kauchali, S.; Marcín, C.; Montiel-Nava, C.; Patel, V.; Paula, C.S.; Wang, C.; et al. Global Prevalence of Autism and Other Pervasive Developmental Disorders: Global Epidemiology of Autism. Autism Res. 2012, 5, 160-179. [CrossRef]

51. Centers for Disease Control and Prevention. Data \& Statistics on Autism Spectrum Disorder; CDC: Atlanta, GA, USA, 2021.

52. Blumberg, S.J.; Bramlett, M.D.; Kogan, M.D.; A Schieve, L.; Jones, J.R.; Lu, M.C. Changes in prevalence of parent-reported autism spectrum disorder in school-aged U.S. children: 2007 to 2011-2012. Natl. Health Stat. Rep. 2011, 20, 55-76.

53. World Population Review. Available online: https://worldpopulationreview.com/country-rankings/education-rankings-bycountry (accessed on 24 February 2022).

54. Kara, M.; Kukul, V.; Çakır, R. Self-regulation in Three Types of Online Interaction: How Does It Predict Online Pre-service Teachers' Perceived Learning and Satisfaction? Asia-Pac. Educ. Res. 2021, 30, 1-10. [CrossRef]

55. Ruggiero, D.; Mong, C.J. The Teacher Technology Integration Experience: Practice and Reflection in the Classroom. J. Inf. Technol. Educ. Res. 2015, 14, 161-178. [CrossRef]

56. Syriopoulou-Delli, C.K.; Polychronopoulou, S.A. Organization and management of the ways in which teachers and parents with children with ASD communicate and collaborate with each other. Int. J. Dev. Disabil. 2017, 65, 31-48. [CrossRef] [PubMed]

57. Sakız, H.; Tören, Z.; Yıldırım, H. Student and Parent Perceptions of Government-Funded Private Special Education Schools. SAGE Open 2021, 11, 215824402110213. [CrossRef]

58. Paul, R. Interventions to Improve Communication in Autism. Child Adolesc. Psychiatr. Clin. N. Am. 2008, 17, 835-856. [CrossRef] [PubMed]

59. Ho, F.C.; Lam, C.S.-C.; Sam, S.K.-L.; Arthur-Kelly, M. An exploratory study on collaborative modes of professional development and learning for teachers of students with autism spectrum disorder (ASD): Collaborative Modes of Professional Development and Learning. Support Learn. 2018, 33, 142-164. [CrossRef]

60. Denning, C.B.; Moody, A.K. Supporting Students with Autism Spectrum Disorders in Inclusive Settings: Rethinking Instruction and Design. Electron. J. Incl. Educ. 2013, 3, 6.

61. Goldstein, G.; Johnson, C.R.; Minshew, N.J. Attentional Processes in Autism. J. Autism Dev. Disord. 2001, 31, 433-440. [CrossRef]

62. Ozonoff, S.; Strayer, D.L. Further Evidence of Intact Working Memory in Autism. J. Autism Dev. Disord. 2001, 31, 257-263. [CrossRef] 
63. Montes, C.D.P.G.; Cara, M.J.C.; Capperucci, D. Plataformas webs y recursos online centrados en habilidades comunicativolingüísticas para familias de personas con autismo. Rev. RETOS XXI 2020, 4. [CrossRef]

64. Gallardo-Montes, C.; Cara, M.C.; Moya, E.C.; Fernández, S.J. Assessment of Apps Aimed at Developing Basic Instrumental Skills in Autistic Children and Teenagers. Mathematics 2021, 9, 1032. [CrossRef]

65. Ali, N.; Smith, I.; Brine, S.; Corkum, P. Usability of an Online Intervention Programme for Teachers of Students with Autism Spectrum Disorder. Int. J. Disabil. Dev. Educ. 2021, 1-17. [CrossRef]

66. Sam, A.M.; Kucharczyk, S.; Waters, V. Online Tools to Support the Delivery of Evidence-Based Practices for Students With ASD. Teach. Except. Child. 2018, 50, 141-152. [CrossRef]

67. Ramdoss, S.; Lang, R.; Mulloy, A.; Franco, J.; O’Reilly, M.; Didden, R.; Lancioni, G. Use of Computer-Based Interventions to Teach Communication Skills to Children with Autism Spectrum Disorders: A Systematic Review. J. Behav. Educ. 2011, 20, 55-76. [CrossRef] 